\title{
Evidence That Granulocyte Macrophage-Colony-stimulating Factor Regulates the Distribution and Differentiated State of Dendritic Cells/Langerhans Cells in Human Lung and Lung Cancers
}

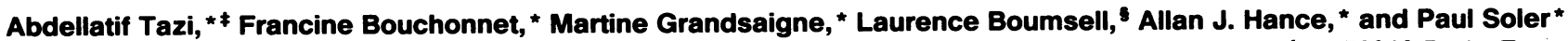

*Institut National de la Santé et de la Recherche Médicale (INSERM) U 82, Faculté de Médecine Xavier Bichat, 75018 Paris, France;

${ }^{\ddagger}$ Service de Pneumologie, Hôpital Avicenne, 93009 Bobigny, France; and ${ }^{\S}$ INSERM U 93, Hôpital Saint Louis, 75010 Paris, France

\begin{abstract}
GM-CSF has been shown to be important for the survival and function of cells of dendritic cell / Langerhans cell ( $\mathrm{LC}$ ) lineage in vitro. Since these cells have been demonstrated to infiltrate human lung and some lung carcinomas, we hypothesized that the production of GM-CSF in the lung could be important in their recruitment and differentiation. Using both immunohistochemistry and in situ hybridization, we have shown that: $(a)$ GM-CSF was produced by normal bronchiolar epithelium, the only site were $\mathrm{CD1a}^{+} \mathrm{LC}$ are observed in the normal lung, whereas neither GM-CSF production nor $L C$ were identified in normal alveolar epithelium. (b) In inflamed pulmonary tissue, hyperplastic alveolar cells produced GM-CSF, and CD1 ${ }^{+} \mathrm{LC}$ accumulated adjacent to these cells. (c) Some, but not all, lung carcinomas produced this cytokine, and a close correlation was found between the production of GM-CSF and the number of $\mathrm{CD1a}^{+} \mathrm{LC}$ infiltrating these tumors. Since GM-CSF was produced at all sites where $\mathrm{CD1a}^{+} \mathrm{LC}$ are known to accumulate, but not at other locations within the lung, these data suggest that the local production of GM-CSF by certain lung cells may play an important role in determining the distribution and differentiated state of dendritic cell / LC in the human lung. ( $J$. Clin. Invest. 1993. 91:566-576.) Key words: granulocyte macrophage-colony-stimulating factor $\bullet$ Langerhans cells $\bullet$ dendritic cells $\bullet$ human lung $\bullet$ lung cancers
\end{abstract}

\section{Introduction}

Dendritic cells (DC) ${ }^{1}$ and Langerhans cells (LC) are potent accessory cells and play an important role in initiating primary immune responses (1-6). Both LC and DC are present in human lung (7-9) and several studies have suggested that these cells, which are considerably better accessory cells than alveolar macrophages $(8,10,11)$, could be involved in the immune defense of this organ $(7,8,10-14)$. LC have been also identi-

Address correspondence to Allan J. Hance, Institut National de la Santé et de la Recherche Médicale U 82, Faculté Xavier Bichat, 16, rue Henri Huchard, 75018 Paris, France.

Received for publication 20 February 1992 and in revised form 29 June 1992.

1. Abbreviations used in this paper: $\mathrm{DC}$, dendritic cells; $\mathrm{LC}$, Langerhans cells.

J. Clin. Invest.

(C) The American Society for Clinical Investigation, Inc.

$0021-9738 / 93 / 02 / 0566 / 11 \$ 2.00$

Volume 91, February 1993, 566-576 fied infiltrating a variety of cancers, including lung cancers (15-18) and a potential role for DC/LC in antitumoral immunity has also been suggested $(19,20)$.

Little is known, however, concerning the factors controlling the number, distribution, and functional activity of cells of DC/LC lineage in the lung. An epithelial microenvironment seems necessary for the presence of LC, since these cells, but not DC, are usually found in association with epithelial cells. LC are present in all squamous epithelia (21). In the lung, LC form a network of cells within the normal tracheal and bronchial epithelium $(7,9,22)$, and are also present in areas of alveolar epithelial hyperplasia or metaplasia $(9,23)$ and among some tumor cells of epithelial origin (15-18). In contrast, DC are found in the peribronchial connective tissue and alveolar interstitium (9).

Several arguments suggest that one factor which could control the presence and differentiation of cells of DC/LC lineage in the lung is the GM-CSF. This cytokine, a 22-kD glycoprotein (24), has been shown to regulate the functional activities of cells of DC/LC lineage in vitro (25-28), and markedly improves the survival in culture of murine epidermal LC (25-27) and human peripheral blood DC (28). Several cell types produce GM-CSF, including epithelial cells and tumor cells (2932). Thus GM-CSF could be produced by epithelial and/or tumor cells in the lung and thereby influence the distribution and differentiation of cells of DC/LC lineage.

To evaluate this hypothesis, we used immunohistochemical techniques and in situ hybridization to localize the sites where GM-CSF was produced in normal and inflamed lung parenchymal tissues and lung tumors. In parallel, we used monoclonal antibodies that specifically recognize either CDla or CD1c molecules expressed by cells of DC/LC lineage and immunohistochemical techniques in order to evaluate the number, distribution, and differentiated state of $\mathrm{DC} / \mathrm{LC}$ in these samples.

\section{Methods}

Patients. Lung tissue was obtained from 14 patients at the time of thoracotomy for localized lung pathology. Three patients had benign tumors (two men, one woman, mean age $41 \pm 21 \mathrm{yr}$, all nonsmokers). 11 patients had localized primary lung carcinoma ( 10 men, 1 woman; mean age $61 \pm 7 \mathrm{yr}, 9$ smokers, 2 nonsmokers). The histologic types of cancer were: squamous cell carcinoma $(n=7)$, adenocarcinoma ( $n$ $=3)$, undifferentiated large cell carcinoma $(n=1)$.

Assessment of tissues. Three types of samples were evaluated separately: tissue containing tumor (tumoral tissue) $(n=11)$, lung tissue immediately adjacent to the tumor $(n=11)$ (peritumoral tissue), and lung tissue taken at a site distant from the lesion $(>10 \mathrm{~cm}$ or taken from a different lobe) for which thoracotomy was performed $(n=11)$. 
For three patients with lung carcinoma, all smokers, tissue distant from the tumor was not available.

For light microscopic examination, lung tissue was fixed in BouinHollande solution, processed by routine techniques, and stained with hematoxylin and eosin. For electron microscopic evaluation (performed on 8 tumors and 10 samples of lung parenchyma), tissue was fixed in $1.7 \%$ glutaraldehyde in PBS buffer ( $\mathrm{pH} \mathrm{7.2)}$ for $1 \mathrm{~h}$ at $4^{\circ} \mathrm{C}$, trimmed to $1-\mathrm{mm}^{3}$ fragments, reimmersed in fixative for $15 \mathrm{~min}$, postfixed with osmium tetroxide, embedded in Epon 812, and 60-nm sections were examined using an electron microscope (EM 410; Philips, Eindhoven, The Netherlands).

Immunohistochemical techniques. Monoclonal antibodies used were: anti-CDla (OKT6; Ortho Diagnostics, Raritan, NJ); anti-CDlc (L161, [33]); Leu-12 (anti-CD19, Becton Dickinson, Mountain View, CA); Leu-M3 (anti-CD14, Becton Dickinson); HLA-DR (anti-HLADR, Becton Dickinson), and an isotype-matched control (MOPC 21; Sigma Chemical Co., St. Louis, MO). The sheep anti-GM-CSF antiserum used in our study was kindly provided by Dr. Mire-Sluis from the National Institute for Biological Standards and Control, South Mimms, Hertfordshire, UK (reference code 89/658). It was produced by immunization of sheep with recombinant human GM-CSF, and was shown to neutralize biological activity of both recombinant and native human GM-CSF in an assay based on the proliferation of GMCSF responsive cells. It was also demonstrated to be specific for GM$\mathrm{CSF}$, in that it did not cross-react with a variety of other cytokines using analogous techniques.

For immunohistochemical staining, tissue fragments were frozen by immersion in liquid $\mathrm{N}_{2}$, lyophilized, and embedded in paraffin as previously described (34). 4- $\mu \mathrm{m}$ sections were deparaffinized and reacted with appropriate dilutions of monoclonal antibodies, washed, and positive cells revealed by reaction with alkaline phosphatase antialkaline phosphatase antibody complexes (APAAP kit system; Dakopatts, Glostrup, Denmark). Sections incubated with sheep anti-GMCSF antibody were reacted with a biotinylated secondary antibody (Multi Link; Dakopatts) and alkaline phosphatase-conjugated streptavidin (Caltag Laboratories, South San Francisco, CA). Positive cells were revealed by reaction with the fast red substrate (Dakopatts). To test the specificity of the immunohistochemical techniques, primary antibodies were omitted or replaced by an isotype-matched control antibody (MOPC 21) or normal sheep serum. In these experiments no positive cells were identified. The intensity of anti-GM-CSF immunostaining was graded from 0 (absent) to ++ (strongly positive); complete agreement was obtained between two independent observers.

Quantitation of CDIa- and CDIc-positive cells. To count positive cells, a grid (ocular test system; Carl Zeiss, Oberkochen, Germany) was inserted in the eyepiece of the microscope to determine the length of bronchiolar epithelium and the surface of tissue evaluated. A length of bronchiolar epithelium corresponding to at least $10 \mathrm{~mm}$ was evaluated. In all samples, a surface of peritumoral and normal lung tissue corresponding to $10 \mathrm{~mm}^{2}$ was evaluated. Because the distribution of positive cells in lung carcinoma was nonuniform, the entire surface of each tumor tissue section was counted. Positive cells present among the malignant cells and those present in the stroma of the tumor were counted separately. To determine the number of $\mathrm{CDIa}^{+}$and $\mathrm{CDIc}^{+}$ cells within a given biopsy, serial sections stained with the two antibodies were compared. Interobserver variation was $<10 \%$. Results are expressed as mean \pm SD. Statistical comparisons were made using the Mann-Whitney test or paired Wilcoxon test.

Independent of assessment of DC/LC, histologic sections of peritumoral tissue and tissue distant from lesion were separated in two groups according to the presence or absence of alveolar epithelial hyperplasia, as defined by the increase in number of type II pneumocytes such that they represented a large portion of the alveolar lining. Other abnormalities identified in these biopsies associated with cigarette smoking ( $n$ $=9$ ) or occupational exposure to inorganic dust $(n=2)$ (e.g., mild diffuse or focal fibrotic changes and the presence of pigment-laden macrophages) were not considered in distinguishing tissues with and without alveolar epithelial hyperplasia.
Hybridization histochemical techniques. The sites within human lung tissue where mRNA for GM-CSF was being actively transcribed were evaluated by in situ hybridization. Small pieces of tissue containing tumor, peritumoral tissue, or normal lung parenchyma $(n=3)$ were snap frozen in liquid $\mathrm{N}_{2}$. Cryostat sections $(6-8 \mu \mathrm{m})$ were cut at $-20^{\circ} \mathrm{C}$, fixed with $4 \%$ paraformaldehyde, rinsed in PBS, dehydrated in ethanol, dried with air, and stored at $-80^{\circ} \mathrm{C}$ until use.

A cloned human GM-CSF cDNA (provided by Dr. J. F. Delamarter, Glaxo Laboratories, Geneva, Switzerland) (35) was used to prepare single-stranded RNA sense and antisense probes. Radiolabeled RNA probes (sp act $1-2 \times 10^{8} \mathrm{dpm} / \mu \mathrm{g}$ DNA template) were prepared using the riboprobe system (Promega Corp., Madison, WI) by transcription of the linearized double-stranded DNA template using ${ }^{35} \mathrm{~S}$ UTP ( $1,000 \mathrm{Ci} / \mathrm{mmol}$; Amersham International, Amersham, UK) as described by the manufacturer.

For in situ hybridization, slides were thawed and rinsed in $2 \times$ standard saline citrate buffer (SSC; $150 \mathrm{mM} \mathrm{NaCl}, 15 \mathrm{mM} \mathrm{Na}$ citrate, $\mathrm{pH}$ $=7.0$ ). The hybridization procedure was performed as described by Bernaudin et al. (36) with minor modifications. Briefly, the hybridization mixture contained the labeled RNA probe $\left(10^{6} \mathrm{dpm} / \mathrm{slide}\right), 50 \%$ formamide, $10 \mathrm{mM}$ DTT, $100 \mu \mathrm{g} / \mathrm{ml}$ salmon sperm DNA, $600 \mu \mathrm{g} / \mathrm{ml}$ yeast tRNA in $2 \times \mathrm{SSC}$. After hybridization at $42^{\circ} \mathrm{C}$ overnight, the slides were immersed in three changes of $50 \%$ formamide $/ 2 \times$ SSC containing $5 \mathrm{mM} \mathrm{DTT}$ at $52^{\circ} \mathrm{C}$, washed in $2 \times \mathrm{SSC}$ at $20^{\circ} \mathrm{C}$, and incubated in $100 \mu \mathrm{g} / \mathrm{ml}$ RNAse A (Sigma Chemical Co.) at $37^{\circ} \mathrm{C}$ for 30 min. The slides were subsequently washed, dehydrated sequentially in ethanol, dried, and processed for autoradiography. After a 2-wk exposure, the slides were developed and stained with hematoxylin and eosin.

Hybridization to normal human skin and the human bladder cancer cell line 5637, both of which produce GM-CSF $(29,30)$, were evaluated as positive controls. The reaction of lung tissue with the "sense" probe was used to evaluate nonspecific binding.

\section{Results}

\section{Comparison of the distribution of DC/LC and that of cells containing GM-CSF}

Lung tissue taken at distance from lesion. In histologically normal lung tissue from nonsmokers $(n=5)$, or tissue displaying abnormalities associated with tobacco consumption but without alveolar epithelial hyperplasia $(n=4)$, the distribution of cells containing GM-CSF, as detected by immunohistochemical staining with anti-GM-CSF antibodies, was quite restricted. Bronchiolar epithelial cells were uniformly positive (Fig. $1 \mathrm{~A}$ ). The endothelium of both blood and lymphatic vessels located in peribronchial and subpleural connective tissue sheathes were also frequently positive. In all cases, positive cells were diffusely stained, suggesting an intracytoplasmic distribution of GM-CSF. In contrast, alveolar epithelial cells, capillary endothelial cells, interstitial cells, lymphocytes, and macrophages were negative for GM-CSF. Alveolar epithelial hyperplasia was present in only two biopsies taken at a distance from the pathological lesion (both smokers). These hyperplastic alveolar epithelial cells, but not the surrounding normal alveolar epithelium, were positive for GM-CSF.

Cells of DC/LC lineage expressing CDla and/or CDlc surface antigens were present in bronchiolar tissues (4.3 \pm 2.1 / $\mathrm{mm}$ and $3.2 \pm 1.6 / \mathrm{mm}$, respectively, for $\mathrm{CDla}^{+}$and $\mathrm{CDlc}^{+}$ cells). In bronchiolar tissues, $\mathrm{CDla} \mathrm{a}^{+}$cells were almost exclusively observed interspersed between bronchiolar epithelial cells (Fig. $1 B$ ), whereas $\mathrm{CD} 1 \mathrm{c}^{+}$cells were predominant in the peribronchiolar connective tissue (Fig. 1C).

As previously described (9), the majority of CD1-positive 

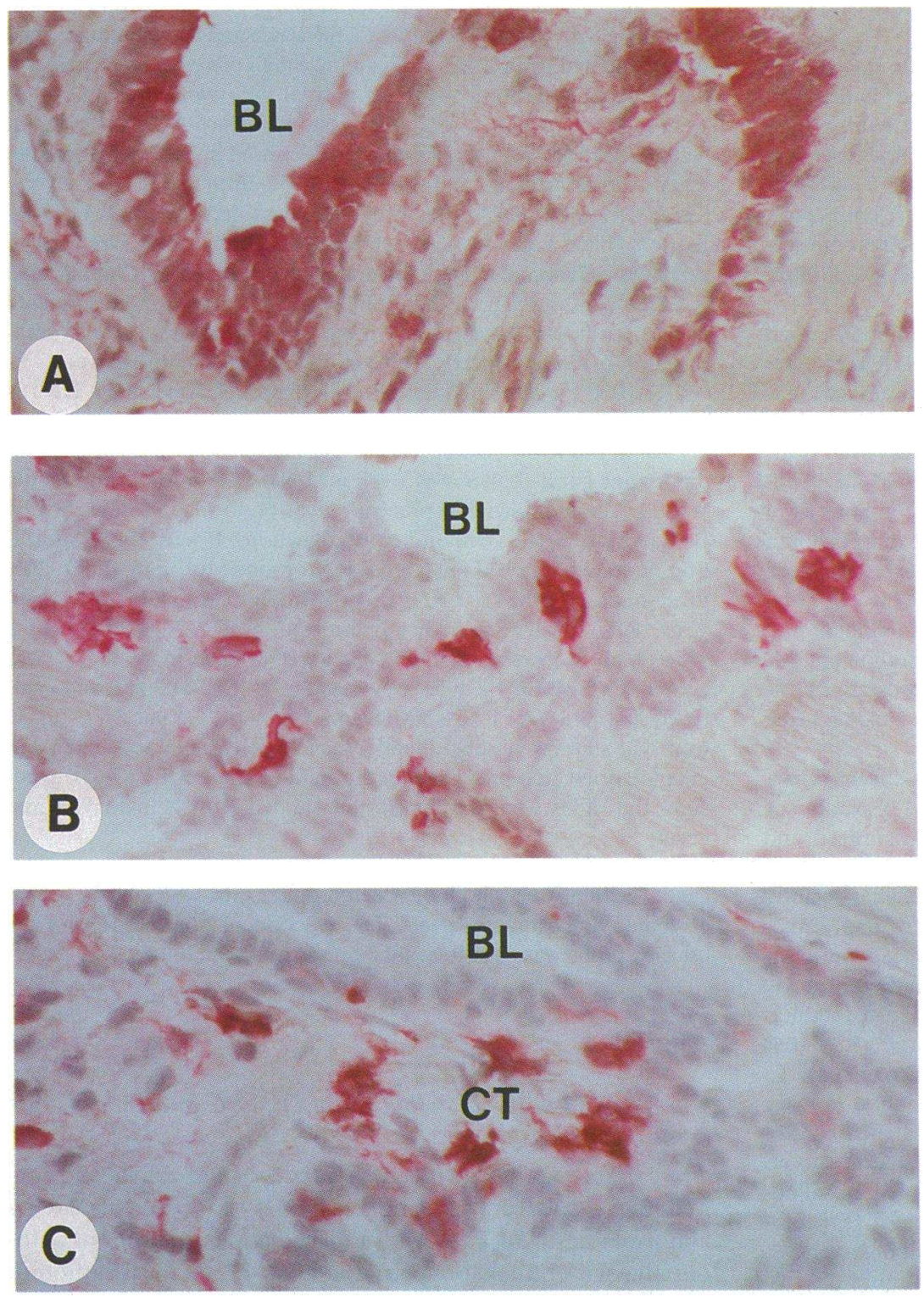

Figure 1. Production of GM-CSF and distribution of cells of $\mathrm{DC} / \mathrm{LC}$ lineage in normal lung tissue. (A) A positive reaction with anti-human GM-CSF antibody was detected in bronchiolar epithelium but not in normal alveolar parenchyma. $(B)$ $\mathrm{CDla}^{+}$cells were identified in the same sites and displayed a dendritic shape in areas where bronchiolar epithelium was cut tangentially. $(C)$ $\mathrm{CD}_{1}{ }^{+}$cells were predominant in the peribronchiolar connective tissue $(C T)$ just beneath epithelium. $B L$, bronchiolar lumen $(\times 300)$. cells in normal alveolar parenchymal tissues expressed the $\mathrm{CDla}^{-} / \mathrm{CDlc}^{+}$phenotype (Table I). The number of $\mathrm{CDla}^{+}$ cells was somewhat increased in the two biopsies containing alveolar hyperplasia, and almost all $\mathrm{CDIa}^{+}$cells were present within the hyperplastic epithelium. Because of the small number of samples with hyperplasia, statistical comparisons could not be made. It is noteworthy that the degree of alveolar epithelial hyperplasia in these tissues taken at a distance from the pathologic lesions was considerably less than that observed adjacent to the lesions (see below). Smoking, in the absence of alveolar hyperplasia, was not associated with an increase in the number of $\mathrm{CDla}^{+}$cells $(P>0.2$ comparing the number of $\mathrm{CDIa}^{+}$and $\mathrm{CD}_{\mathrm{c}}{ }^{+}$cells in normal parenchyma from smokers and nonsmokers).

Lung parenchyma adjacent to lung carcinomas. In the tissue adjacent to, but not infiltrated by lung carcinomas, bronchiolar epithelial cells and vascular and lymphatic endothelial cells in the bronchovascular sheath were also positive for GM-
Table I. Distribution of Cells of DC/LC Lineage in Peritumoral Lung Tissue and in Tissue Taken at a Distance from Pathological Lesions

\begin{tabular}{|c|c|c|c|c|}
\hline \multirow[b]{2}{*}{ Tissue location } & \multirow[b]{2}{*}{$\begin{array}{c}\text { Smokers/ } \\
\text { nonsmokers }\end{array}$} & \multicolumn{3}{|c|}{ CD1 positive cells in lung parenchyma } \\
\hline & & $\begin{array}{l}\mathrm{CD1 \textrm {a } ^ { + }} \\
\text { cells } / \mathrm{mm}^{2}\end{array}$ & $\begin{array}{l}\mathrm{CD}^{\mathrm{C}} \mathrm{c}^{+} \\
\text {cells } / \mathrm{mm}^{2}\end{array}$ & $\begin{array}{l}\mathrm{CD} 1 \mathrm{a} / \mathrm{CD} 1 \mathrm{c} \\
\text { ratio }\end{array}$ \\
\hline $\begin{array}{l}\text { Adjacent to lung } \\
\text { carcinomas }\end{array}$ & $9: 2$ & & & \\
\hline Alveolar hyperplasia & $3: 2$ & $14.6 \pm 11.1^{*}$ & $10.7 \pm 5.4$ & $1.3 \pm 0.7^{*}$ \\
\hline No hyperplasia & $6: 0$ & $1.1 \pm 0.8$ & $4.0 \pm 1.7$ & $0.3 \pm 0.2$ \\
\hline $\begin{array}{l}\text { Distant from pathologic } \\
\text { lesion }\end{array}$ & $6: 5$ & & & \\
\hline Alveolar hyperplasia & $2: 0$ & $4.9 \pm 0.8$ & $13.5 \pm 12.3$ & $0.5 \pm 0.5$ \\
\hline No hyperplasia & $4: 5$ & $2.2 \pm 1.5$ & $10.3 \pm 8.1$ & $0.3 \pm 0.1$ \\
\hline
\end{tabular}

* $P<0.01$ compared results of samples with no hyperplasia in both locations Tissue distant from the pathologic lesion was not available for three patients with carcinoma (all smokers). 
CSF. The intensity of staining at these sites was not, however, strikingly different from that of normal lung. Similarly, no differences in the number and distribution of DC/LC in bronchiolar structures were observed $\left(\mathrm{CDla}^{+}\right.$cells: $5.3 \pm 2.6 / \mathrm{mm}$, $\mathrm{CD}^{+}{ }^{+}$cells: $2.4 \pm 1.0 / \mathrm{mm}, P>0.2$ compared to number of positive cells in tissue taken at distance from lesion).

In the samples of peritumoral lung tissue that did not contain hyperplastic alveolar epithelium $(n=6)$, no GM-CSF production by alveolar parenchyma was noted and the number and distribution of cells of $\mathrm{DC} / \mathrm{LC}$ lineage was not different from that of lung tissue distant from lesion (Table I).

In contrast, hyperplastic alveolar epithelial cells in peritumoral tissue from five patients were strongly positive for GMCSF (Fig. $2 \mathrm{~A}$ ). In these samples, large numbers of $\mathrm{CD}^{2} \mathrm{a}^{+}$cells were always observed adjacent to and infiltrating areas of alveolar epithelial hyperplasia. Overall, the number of $\mathrm{CDIa}^{+}$ cells in lung parenchyma was dramatically increased comparing these specimens and either peritumoral tissue without alveolar hyperplasia or lung tissue taken at a distance from lesion ( Table I). This increase in the number of $\mathrm{CDla}^{+}$cells was particularly prominent in specimens with extensive alveolar hyperplasia (data not shown). Since the number of CDIc ${ }^{+}$ cells was not increased in peritumoral tissue containing areas of hyperplastic alveolar epithelium, the ratio of $\mathrm{CDla}^{+} / \mathrm{CDIc}^{+}$ cells in these specimens was significantly increased compared to both peritumoral or distant lung tissue without alveolar hyperplasia (Table I).

Unlike lymphocytes present in normal lung tissue, the lymphocytes infiltrating lung parenchyma adjacent to carcinomas were faintly but uniformly positive for GM-CSF (Fig. $2 \mathrm{~B}$ ).

Lung carcinomas. Reactivity of lung carcinomas with the anti-GM-CSF antibody was extremely variable. The most intensely positive reaction was noted in four poorly differentiated squamous cell carcinomas (Fig. $3 C$ ). The remaining tumor of this type, however, was repeatedly negative for GM-CSF (Fig. 3 $A$ ). In differentiated squamous cell carcinomas only some tumor cells were positive for GM-CSF. In particular, less well differentiated cells, usually present at the periphery of the tumor nodules, were moderately positive for GM-CSF, whereas tumor cells which were well differentiated (e.g., those containing keratic whirls) were negative. All adenocarcinomas studied were moderately and diffusely positive for GM-CSF (Fig. $3 B$ ), while the single undifferentiated large cell carcinoma was negative.
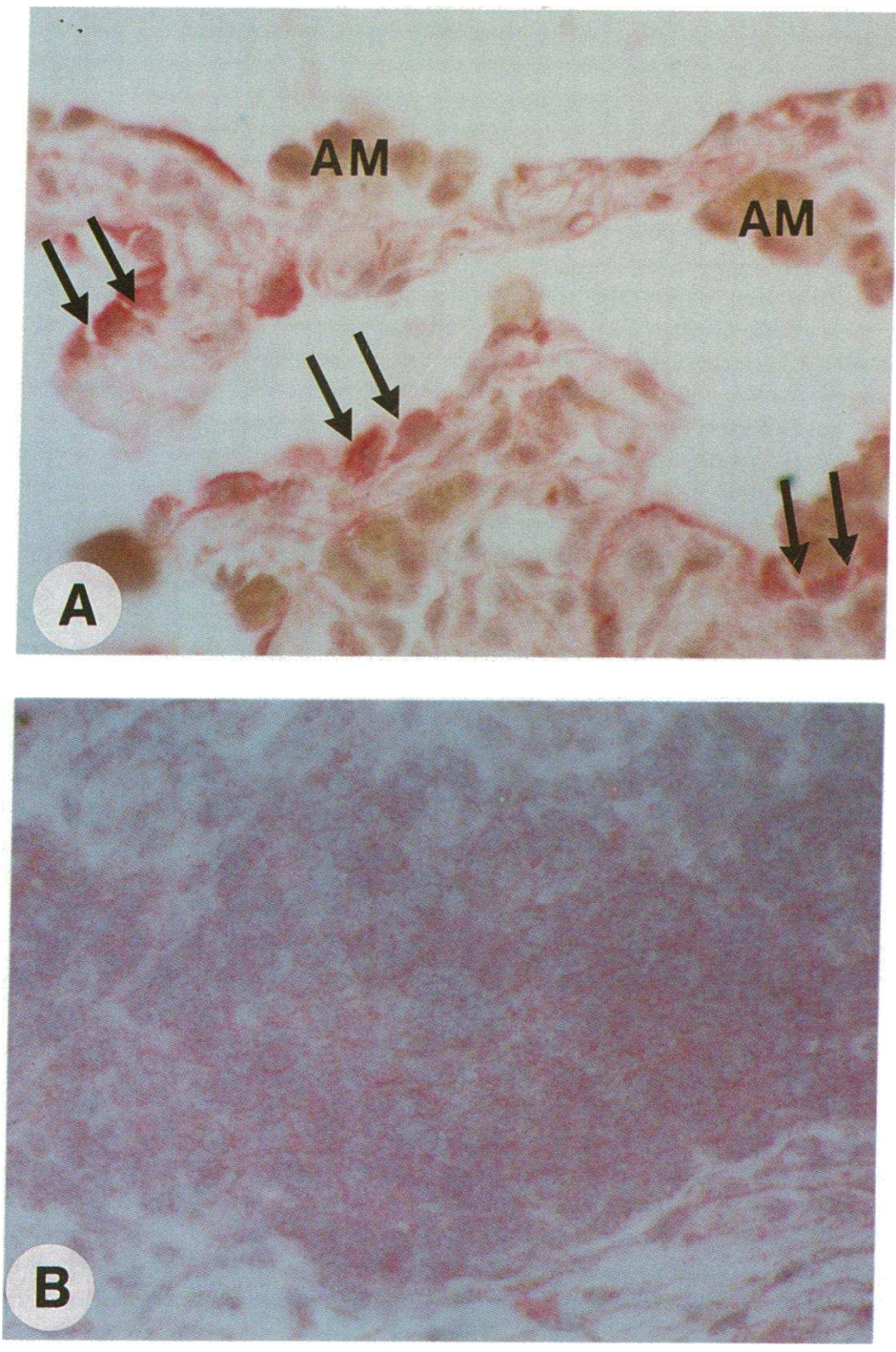

Figure 2. Production of GM-CSF in peritumoral lung tissue. $(A)$ Areas of hyperplastic alveolar epithelial cells were positive for GM-CSF (arrows). (B) Lymphocytes heavily infiltrated lung parenchyma adjacent to carcinomas and were faintly positive for GM-CSF. $A M$, alveolar macrophages $(\times 300)$. 

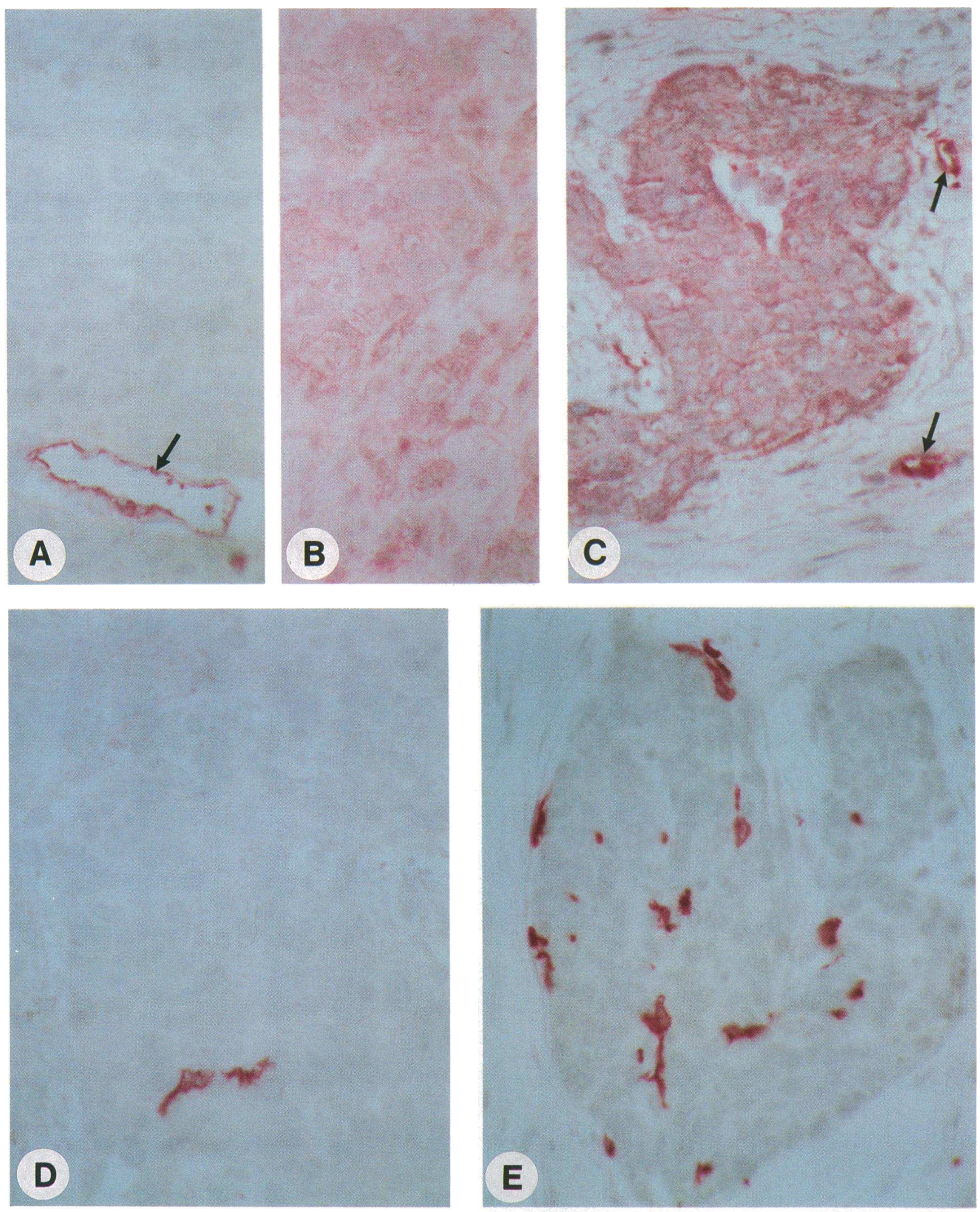

Figure 3. Correlation between the presence of $\mathrm{CDla}^{+}$cells and the production of GM-CSF by lung cancers. $(A)$ A squamous cell carcinoma negative for GM-CSF immunodetection although endothelial cells are reactive (arrows). ( $B$ ) Adenocarcinoma showing a positive reaction of tumor cells with anti-GM-CSF antibody graded + . $(C)$ Squamous cell carcinoma showing a strong positive reaction of tumor cells with antiGM-CSF antibody graded ++ . Note that vascular endothelial cells are intensively reactive (arrow). (D) The tumor negative for GM-CSF contained very few $\mathrm{CDla}^{+}$cells. $(E)$ Serial section of the same tissue specimen shown in $(C)$ containing numerous $\mathrm{CD} \mathrm{a}^{+}$cells infiltrating the tumor nodule. $(A, B$, and $D, \times 350 ; C$ and $E, \times 250)$. 
The extent of infiltration of carcinomas by DC/LC was also extremely variable. The histologic type of the tumor per se was not predictive of the number of CD1-positive cells present in the specimen $(P>0.1$ for all comparisons of the number of $\mathrm{CDI} \mathrm{a}^{+}$and $\mathrm{CD} 1 \mathrm{c}^{+}$cells $/ \mathrm{mm}^{2}$ in tumors of different histologic type). Strikingly, without exception, a close correlation was observed between the number of $\mathrm{CD} 1^{+}$cells present in a given tumor and the reactivity of the tumor cells with the anti-GMCSF antibody. Tumors which were strongly positive for GMCSF were also heavily infiltrated by $\mathrm{CD} \mathrm{la}^{+}$cells (Fig. $3 E$ ), whereas the poorly differentiated squamous cell carcinoma specimen which was negative for GM-CSF contained very few $\mathrm{CD} \mathrm{a}^{+}$cells (Fig. $3 \mathrm{D}$ ).

The distribution of $\mathrm{DC} / \mathrm{LC}$ within a given carcinoma was also closely correlated with the distribution of GM-CSF-containing tumor cells. Tumors that were diffusely positive for GM-CSF were also diffusely infiltrated by DC/LC. In the case of differentiated squamous cell carcinomas, both the less well differentiated tumor cells (which were positive for GM-CSF) and DC/LC were predominant at the periphery of the tumor nodules, whereas $\mathrm{CDI}^{+}$cells were not observed infiltrating the well differentiated tumor cells (which were GM-CSF negative).

In the connective tissue stroma surrounding the lung carcinomas, only the endothelial cells of tumor vessels were strongly reactive with anti-GM-CSF antibodies (Fig. 3). The number of $\mathrm{CDI}^{+}$cells in the stroma was considerably smaller than that in the adjacent tumor (stroma: $2.6 \pm 4.3 \mathrm{CDla}^{+}$cells $/ \mathrm{mm}^{2}$ and $2.2 \pm 2.2 \mathrm{CD} \mathrm{c}^{+}$cells $/ \mathrm{mm}^{2}$; among tumor cells: $26.7 \pm 23.8$ $\mathrm{CDla}^{+}$cells $/ \mathrm{mm}^{2}$ and $13.0 \pm 9.4 \mathrm{CD} 1 \mathrm{c}^{+}$cells $/ \mathrm{mm}^{2} ; P<0.01$ for both comparisons).

\section{Further characterization of $D C / L C$ in lung carcinomas}

Essentially all $\mathrm{CDIa}^{+}$and $\mathrm{CD} \mathrm{c}^{+}$cells infiltrating lung carcinomas had a characteristic dendritic shape, and long cytoplasmic processes extending between the neoplastic cells were frequently observed (Fig. 4). These cells were $\mathrm{CDI1}^{-}, \mathrm{CD}^{-} 9^{-}$, and HLA-DR ${ }^{+}$(not shown). In all tumors, the number of cells $/ \mathrm{mm}^{2}$ expressing CDla was greater than that expressing $\mathrm{CD} 1 \mathrm{c}$, indicating that cells with the $\mathrm{CDIa}^{+} / \mathrm{CDIc}^{-}$phenotype typical of pulmonary LC were present. Both the absolute number and relative proportion of $\mathrm{CDIa}^{+} / \mathrm{CDIc}^{-}$cells were greater in tumors which were strongly positive for GM-CSF (Fig. 5).

Electron microscopic evaluation confirmed the presence of typical LC containing Birbeck granules among malignant cells in specimens heavily infiltrated by $\mathrm{CDla}^{+}$cells (Fig. 6). In these tumors, LC were closely associated with the malignant cells. In regions of contact between the $\mathrm{LC}$ and tumor cells, localized areas of increased density of the adjoining cell membranes were observed, and electron dense material filled the intercellular space (Fig. 6, inset). In tumor specimens containing few $\mathrm{CD} \mathrm{a}^{+}$cells, cells with a dendritic shape were rarely observed and cells containing Birbeck granules were not found.
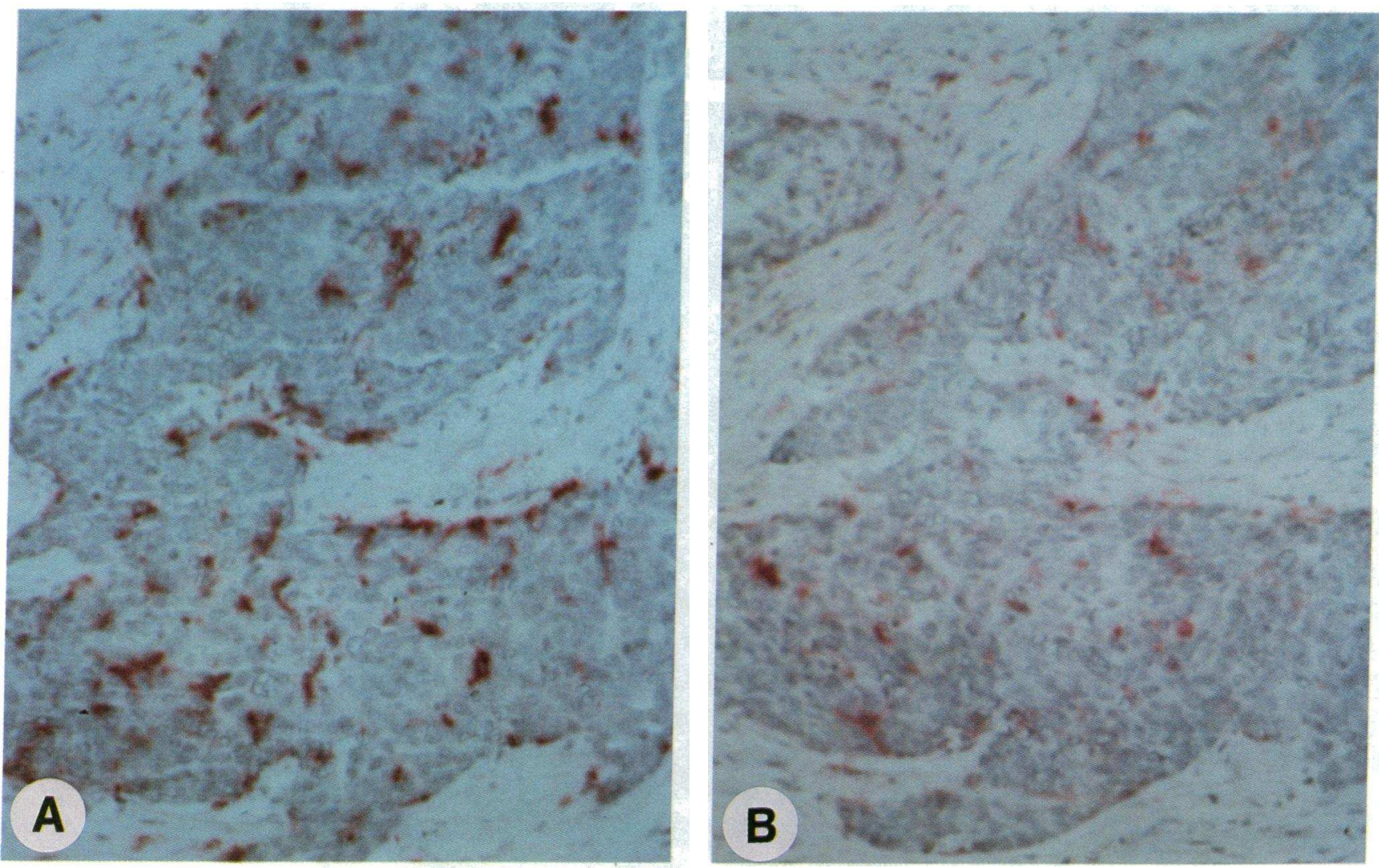

Figure 4. Cells of DC/LC lineage infiltrating a squamous cell carcinoma. $(A)$ Numerous $\mathrm{CDIa}^{+}$cells within a tumor nodule. Positive cells appear dendritic in shape and interspersed among malignant cells $(\times 125)$. $(B)$ Another section of the same tumor nodule showing infiltration by $C D 1 c^{+}$ cells $(\times 125)$. 


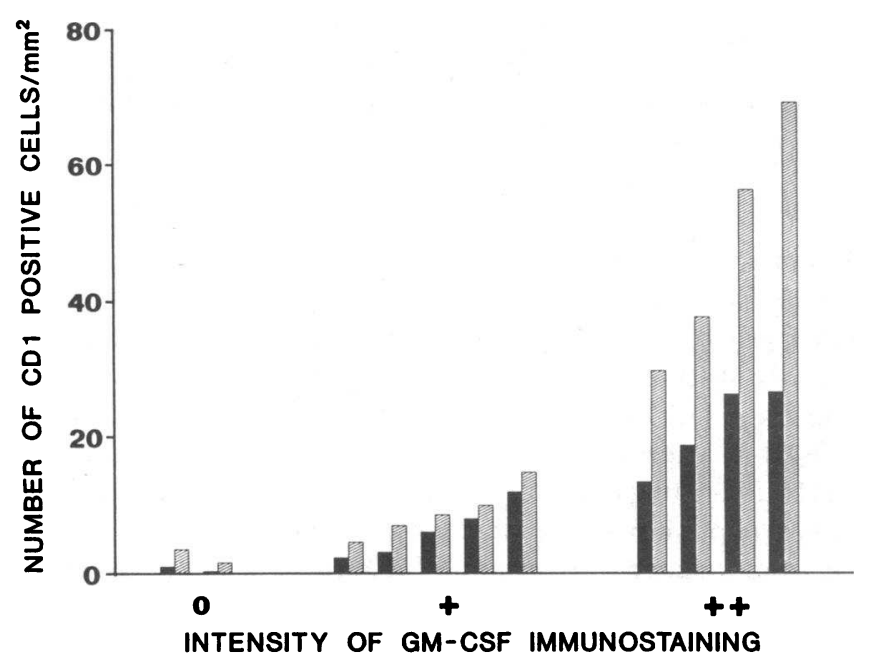

Figure 5. Correlation between the numbers of cells of DC/LC lineage infiltrating lung carcinomas and the intensity of immunostaining with anti-human GM-CSF graded from $(-)$ to $(++) . \mathrm{CDla}^{+}$cells $(\mathbb{\otimes})$ were constantly more numerous than $\mathrm{CDIc}^{+}$cells $(\bullet)$. A close correlation was observed between the intensity of immunostaining with anti-GM-CSF antibody and the number of intratumoral CD1a ${ }^{+}$cells.
Typical LC containing Birbeck granules were also observed in regions of alveolar epithelial hyperplasia in parenchyma adjacent to tumors (not shown).

\section{Detection of GM-CSF MRNA by in situ hybridization}

To confirm that the cells stained with anti-GM-CSF antibody were capable of synthesizing this cytokine, we evaluated the expression of mRNA for GM-CSF by in situ hybridization. Analysis of autoradiograms of three specimens of normal and inflamed lung tissue constantly demonstrated easily detectable expression of GM-CSF mRNA transcripts by bronchiolar epithelial cells and hyperplastic alveolar epithelial cells (Fig. 7). Positive cells exhibited 15-50 silver grains over and adjacent to their nuclei. In contrast, normal alveolar epithelium and the parenchymal cells of the alveolar interstitium and peribronchiolar tissue were negative. Some intraalveolar macrophages, but not interstitial macrophages, and endothelial cells also showed evidence of GM-CSF expression. Incubation of the samples with the labeled sense RNA probe showed little or no hybridization (0-5 grains/cell).

Analysis of autoradiograms of three squamous cell carcinomas, all of which were positive with the anti-GM-CSF antibody, demonstrated that almost all tumor cells hybridized with
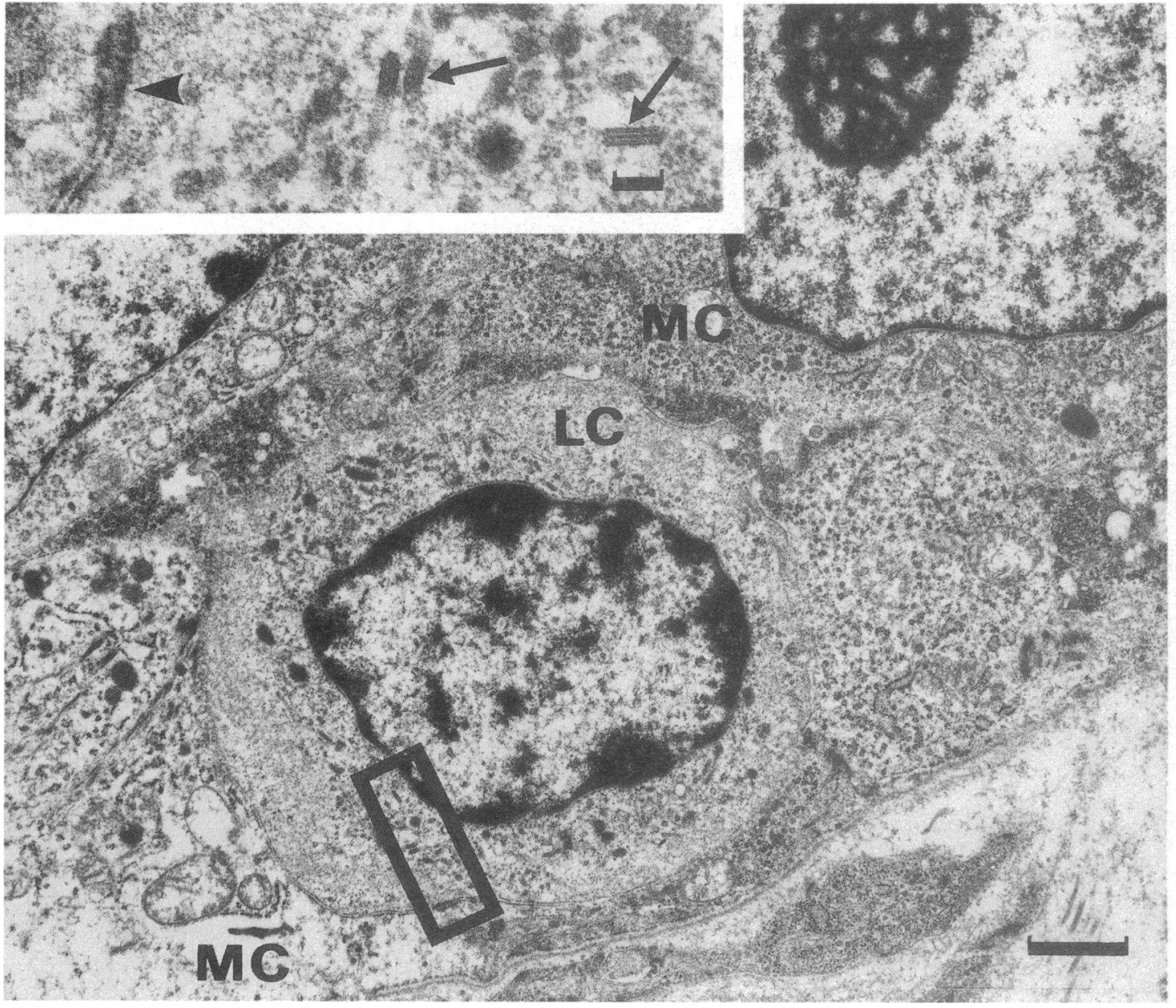

Figure 6. Squamous cell carcinoma. Electron micrograph showing a Langerhans cell $(L C)$ in close association with malignant cells $(M C)$. Bar $=1 \mu \mathrm{m}$. (Inset) Detail of the framed region of LC showing typical Birbeck granules (arrows) and a differentiated contact with the surrounding malignant cell (arrowhead). Bar $=0.1 \mu \mathrm{m}$. 

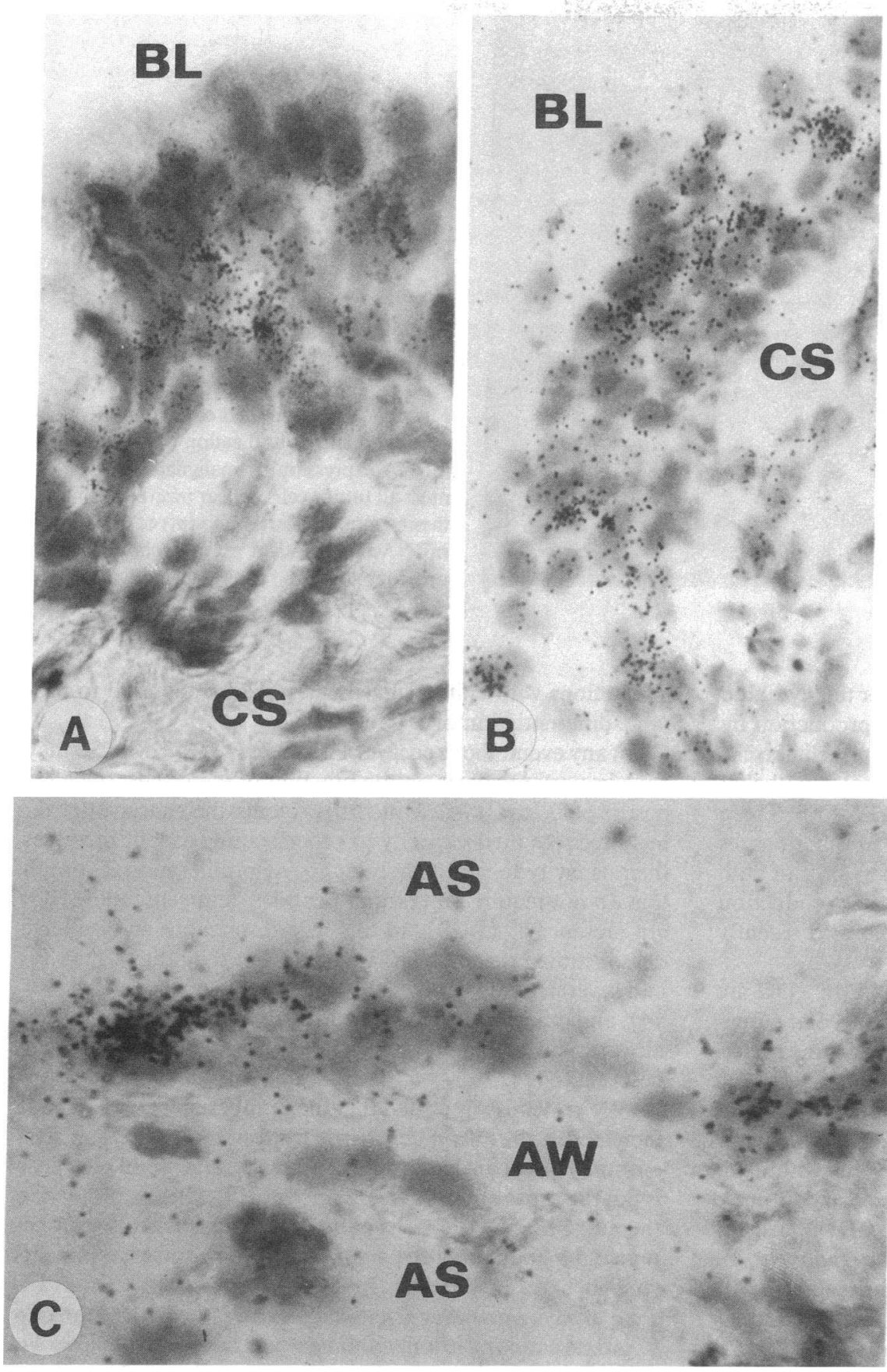

Figure 7. Evaluation by in situ hybridization of GM-CSF mRNA expression in human lung parenchymal tissue. $(A$ and $B$ ) High power views of two bronchioles of different size showing silver grains deposits above epithelial cells only. $B L$, bronchiolar lumen; $C S$, connective tissue sheath $(\times 1,000)$. $(C)$ High power view of an alveolar wall $(A W)$ showing positive hyperplastic epithelial cells. $A S$, alveolar space $(\times 1,250)$. the labeled antisense RNA-GM-CSF probe. The silver grains were diffusely distributed over positive cells, some of them expressing large amounts of GM-CSF mRNA transcripts (Fig. 8). Quantitative evaluation of the samples demonstrated that $>75 \%$ of malignant cells showed strong deposition of silver grains (25-85 grains/cell). In contrast to the antisense RNA probe, the labeled sense RNA-GM-CSF probe showed little or no hybridization to malignant cells (0-5 grains/cell).

\section{Discussion}

This study, performed using combined immunohistochemical and in situ hybridization techniques demonstrates that: $(a)$ GM-CSF is produced by normal bronchiolar epithelium, the only site where $\mathrm{CDIa}^{+} \mathrm{LC}$ are observed in the normal lung; (b) in inflamed pulmonary tissue, hyperplastic alveolar epithelial cells and, to a lesser degree, lymphocytes also produce GM$\mathrm{CSF}$, and $\mathrm{CDIa}^{+}$cells accumulate adjacent to these cell types; (c) some, but not all, lung carcinomas produce GM-CSF, and a close correlation exists between the production of GM-CSF and the number of $\mathrm{CDIa}^{+} \mathrm{LC}$ infiltrating these tumors. Taken together, these data suggest that the local production of GMCSF by certain lung cells may play an important role in determining the distribution and differentiated state of DC/LC in the human lung.

GM-CSF and cells of $D C / L C$ lineage in human lung. The production of GM-CSF in normal lung parenchymal tissue was restricted to relatively few cell types. Only bronchiolar epithelial cells and the endothelial cells of larger vessels and lym- 


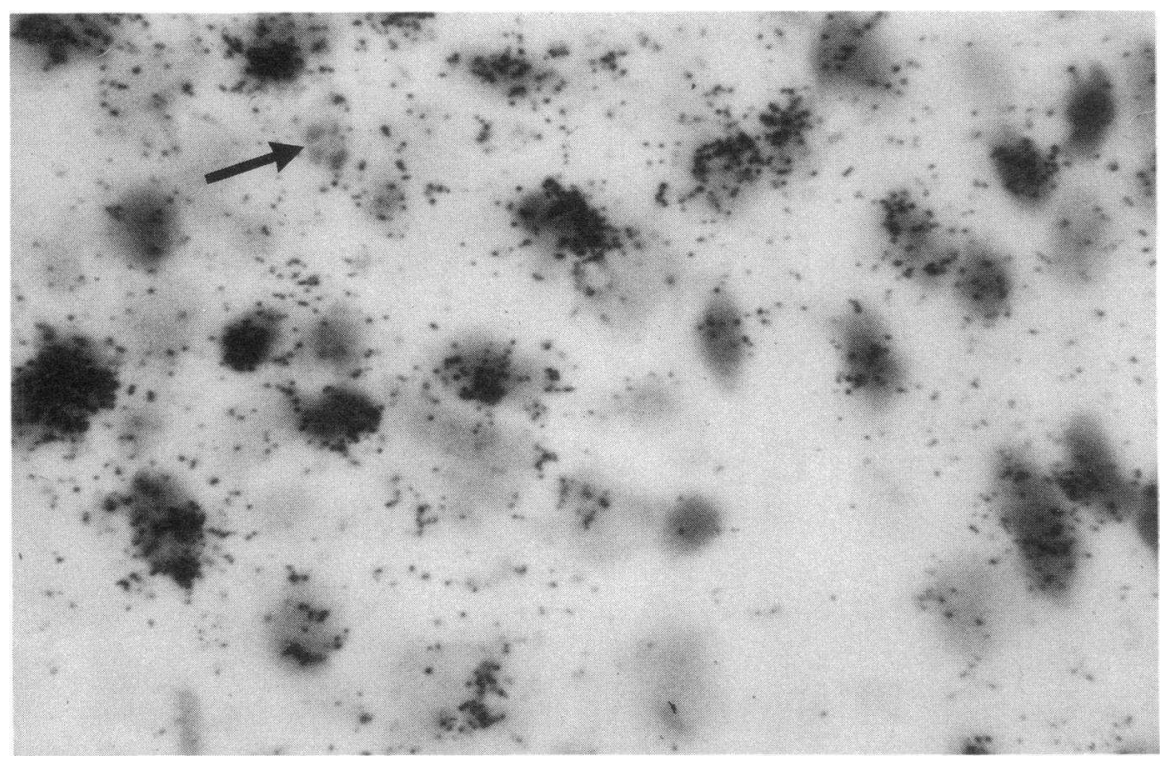

Figure 8. Squamous cell carcinoma. Evaluation by in situ hybridization of GM-CSF mRNA expression by malignant cells. Almost all tumor cells appear positive, some of them containing large amounts of GM-CSF mRNA transcripts. A polymorphonuclear neutrophil (arrow) is not labeled $(\times 1,000)$. phatics were demonstrated to produce mRNA for this cytokine and accumulate the protein product. GM-CSF production by other cell types, including normal alveolar epithelial cells, could not be detected, although hyperplastic alveolar epithelial cells did produce easily detectable amounts of GM-CSF. These findings are compatible with previous studies in other tissues demonstrating the production of this cytokine by cells of both epithelial $(29)$ and endothelial $(37,38)$ origin. The production of GM-CSF by murine tracheal epithelium has also recently been reported (32).

We have previously shown that $\mathrm{CDIa}^{-} / \mathrm{CDIc}^{+} \mathrm{DC}$ are present both in the bronchiolar submucosa and alveolar parenchyma of the normal lung, whereas $\mathrm{CDIa}^{+} \mathrm{LC}$ are found preferentially within the bronchiolar epithelium (9). We suggest that the production of GM-CSF by endothelial cells could promote the recruitment of circulating DC into the lung parenchyma. Once present in the lung, these cells can remain within the connective tissue framework, and in the absence of continued exposure to GM-CSF, these cells display the $\mathrm{CDIa}^{-} / \mathrm{CDIc}^{+}$ phenotype characteristic of pulmonary DC. Alternatively, the production of GM-CSF by normal bronchiolar epithelial cells results in the chemotaxis of DC in the proximity toward the epithelium and promotes their differentiation into $\mathrm{CDla}^{+} /$ $\mathrm{CD}^{+}{ }^{+}$"indeterminate" cells or $\mathrm{CDIa}^{+} / \mathrm{CDIc}^{-} \mathrm{LC}$. In the skin, an analogous differentiation of $\mathrm{CDIa}^{-} / \mathrm{CDIc}^{+} \mathrm{DC}$ into $\mathrm{CDIa}^{+} / \mathrm{CD}^{+} \mathrm{c}^{+}$indeterminate cells and ultimately into $\mathrm{CDIa}^{+} / \mathrm{CDIC}^{-} \mathrm{LC}$ has been described, associated with the migration of these cells from the dermis into the epidermis (39). It is noteworthy that production of GM-CSF by keratinocytes present in the spinous layer (the site of accumulation of LC) has also been reported (29). Further support for GM-CSF-induced recruitment and differentiation of $L C$ comes from the recent observation that the intradermal injection of GM-CSF in patients with leprosy results in a selective accumulation of $\mathrm{CD} \mathrm{a}^{+} \mathrm{LC}$ in the dermis, thought to result from the recruitment and differentiation of precursor DC arriving from the blood (40). The cultivation of LC in vitro in the presence of GM-CSF, however, causes these cells to loose Birbeck granules. Thus, other factors present in the epithelial environment or interactions with epithelial cells may also be required to promote differentiation of DC into LC.

In any event, the exposure of epithelial LC to GM-CSF may have important effects on the function of these cells, since exposure of LC to GM-CSF in vitro prolongs their survival, strikingly reduces their capacity to process antigens, but increases their capacity to stimulate lymphocyte proliferation if stimuli that do not require processing (peptides, mitogens, alloMHC) are present $(6,25-28)$. In this regard, previous studies have demonstrated that LC/DC isolated from the lung of humans and several animal species are potent accessory cells $(7,8,10$ 14 ), and differences in the functional activity of cells present in airways and within the lung interstitium have recently been described (41).

We previously reported that the number of $\mathrm{CDla}^{+} \mathrm{LC}$ was increased in the lung parenchyma from smokers (9). The present study offers further insights in these results. Smoking per se is not the cause of this increase since no difference was noted in the number of $\mathrm{CDIa}^{+}$cells present within normal alveolar parenchyma comparing the smoking and non smoking patients studied here. In contrast, increased numbers of $\mathrm{CDIa}^{+} \mathrm{LC}$ were always present at sites of alveolar epithelial hyperplasia. Cigarette smoking is known to be a common cause of alveolar epithelial hyperplasia, and hyperplasia was observed in most of the biopsies from smokers evaluated in our prior study (9). These results suggest that an increase in LC associated with smoking is dependent upon the development of smoking-induced epithelial hyperplasia. The production of GM-CSF by hyperplastic alveolar epithelium but not by normal alveolar epithelium offers a ready explanation for the presence of increased numbers of pulmonary $\mathrm{CDIa}^{+} \mathrm{LC}$ in these cases.

$G M-C S F$ and cells of DC/LC lineage in lung cancer. Several previous studies have shown that cells of DC/LC lineage accumulate in some but not all cancers (15-18), a finding confirmed here. Although infiltration by $\mathrm{DC} / \mathrm{LC}$ has been found to occur more frequently in certain histologic types (e.g., bronchoalveolar carcinomas and papillary adenocarcinomas) than in others (e.g., large cell), no strict association between histologic type and DC/LC infiltration has been found (15- 
18). Our study demonstrates that the capacity of tumor cells to produce GM-CSF and the amount of this factor produced have an important bearing on the infiltration of the tumor by DC/ LC, thereby explaining the variable degree of infiltration in different tumors. Tumors which were strongly positive for GM-CSF were highly infiltrated, whereas tumors which did not produce GM-CSF were not. Furthermore, tumors producing large amounts of GM-CSF appeared to contain a greater proportion of $\mathrm{CDIa}^{+} / \mathrm{CDIc}^{-} \mathrm{LC}$, and the presence of $\mathrm{LC}$ with typical Birbeck granules was confirmed by electron microscopy. Thus, the level of GM-CSF production may influence not only the number but also the state of differentiation of DC/LC present. Finally, our study indicates that although histologic type per se does not determine whether or not a tumor will be infiltrated by DC/LC, the state of differentiation of the tumor cells can modulate GM-CSF production, and thereby influence DC/LC infiltration. In particular, poorly differentiated squamous cell carcinomas, and undifferentiated cells in otherwise well differentiated squamous cell carcinomas, were frequently found to be positive for GM-CSF, whereas tumor cells with more differentiated features were GM-CSF negative.

Studies in animal models have demonstrated that cells of $\mathrm{DC} / \mathrm{LC}$ lineage can process and present tumor antigens to $\mathrm{T}$ lymphocytes $(19,20)$. Furthermore, the administration of tumor antigen-pulsed $\mathrm{DC} / \mathrm{LC}$ in vivo can induce protective antitumoral immunity (19). The role of LC in initiating immune responses against lung cancers, however, has not been addressed here and merits further study.

In summary, this study has demonstrated that GM-CSF is produced at all sites in the human lung where $\mathrm{CDla}^{+} \mathrm{LC}$ are known to accumulate: bronchiolar epithelia, hyperplastic alveolar epithelia, and certain lung carcinomas. In the context of studies performed in vitro demonstrating effects of GM-CSF on survival and function of LC, these findings suggest that this cytokine may have an important influence on the distribution and differentiation of DC/LC in the lung, and is likely to modify the functional capacities of these important accessory cells.

\section{Acknowledgments}

The authors thank F. Mazin for her excellent technical assistance.

This work was supported in part by a grant 88D6 from the Comité National contre les Maladies Respiratoires et la Tuberculose, and a grant from the Fondation pour la Recherche Médicale.

\section{References}

1. Rowden, G. 1981. The Langerhans cell. Crit. Rev. Immunol. 3:95-180.

2. Van Voorhis, W. C., J. Valinsky, E. Hoffman, J. Luban, L. S. Hair, and R. M. Steinman. 1983. Relative efficacy of human monocytes and dendritic cells as accessory cells for T cell replication. J. Exp. Med. 158:174-191.

3. Schuler, G., and R. M. Steinman. 1985. Murine epidermal Langerhans cells mature into potent immunostimulatory dendritic cells in vitro. J. Exp. Med. 161:526-546.

4. Romani, N., S. Koide, M. Crowley, M. Witmer-Pack, A. M. Livingstone, C. Garrison Fathman, K. Inaba, and R. M. Steinman. 1989. Presentation of exogenous protein antigens by dendritic cells to $T$ cell clones: intact protein is presented best by immature epidermal Langerhans cells. J. Exp. Med. 169:1168-1178.

5. King, P. D., and D. R. Katz. 1990. Mechanisms of dendritic cell function. Immunol. Today. 6:206-211.

6. Steinman, R. M. 1991. The dendritic cell system and its role in immunogenicity. Annu. Rev. Immunol. 9:271-296.

7. Sertl, K., T. Takemura, E. Tschachler, V. J. Ferrans, M. A. Kaliner, and E. M. Shevach. 1986. Dendritic cells with antigen-presenting capability reside in airway epithelium, lung parenchyma, and visceral pleura. J. Exp. Med. 163:436451.
8. Nicod, L. P., M. F. Lipscomb, J. C. Weissler, C. R. Lyons, J. Albertson, and G. B. Toews. 1987. Mononuclear cells in human lung parenchyma: characterization of a potent accessory cell not obtained by bronchoalveolar lavage. Am. Rev. Respir. Dis. 136:818-823.

9. Soler, P., A. Moreau, F. Basset, and A. J. Hance. 1989. Cigarette smokinginduced changes in the number and differentiated state of pulmonary dendritic cells/Langerhans cells. Am. Rev. Respir. Dis. 139:1112-1117.

10. Holt, P. G., M. A. Schon-Hegrad, and J. Oliver. 1988. MHC class II antigen-bearing dendritic cells in pulmonary tissues of the rat. Regulation of antigen presentation activity by endogenous macrophage populations. $J$. Exp. Med. 167:262-274.

11. Nicod, L. P., M. F. Lipscomb, G. M. Toews, and J. C. Weissler. 1989. Separation of potent and poorly functional human lung accessory cells based on autofluorescence. J. Leukocyte Biol. 45:458-465.

12. Rochester, C. L., E. M. Goodell, J. K. Stoltenborg, and W. E. Bowers. 1988. Dendritic cells from rat lung are potent accessory cells. Am. Rev. Respir. Dis. 138:121-128.

13. Pollard, A. M., and M. F. Lipscomb. 1990. Characterization of murine lung dendritic cells: similarities to Langerhans cells and thymic dendritic cells. $J$. Exp. Med. 172:159-167.

14. Hance, A. J. 1991. Accessory-cell T-lymphocyte interactions. In The Lung: Scientific Foundations. R. G. Crystal and J. B. West, editors. Raven Press, Ltd., New York. 483-496.

15. Watanabe, S., Y. Sato, T. Kodama, and Y. Shimosato. 1983. Immunohistochemical study with monoclonal antibodies on immune response in human lung cancers. Cancer Res. 43:5883-5889.

16. Furukawa, T., S. Watanabe, T. Kodama, Y. Sato, Y. Shimosato, and K. Suemasu. 1985. T-zone histiocytes in adenocarcinoma of the lung in relation to postoperative prognosis. Cancer (Phila.). 56:2651-2656.

17. Hammar, S., D. Bockus, F. Remington, and M. Bartha. 1986. The widespread distribution of Langerhans cells in pathologic tissues: an ultrastructural and immunohistochemical study. Hum. Pathol. 17:894-905.

18. Fox, S. B., M. Jones, M. S. Dunnill, K. G. Gatter, and D. Y. Mason. 1989. Langerhans cells in human lung tumours: an immunohistological study. Histopathology (Oxf.). 14:269-275.

19. Knight, S. C., R. Hunt, C. Dore, and P. B. Madawar. 1985. Influence of dendritic cells on tumor growth. Proc. Natl. Acad. Sci. USA. 82:4495-4497.

20. Grabbe, S., S. Bruvers, R. L. Gallo, T. L. Knisely, R. Nazareno, and R. D. Granstein. 1991. Tumor antigen presentation by murine epidermal cells. J. Im munol. 146:3656-3661.

21. Friedmann, P. S. 1981. The immunobiology of Langerhans cells. Immunol. Today. 2:124-128.

22. Schon-Hegrad, M. A., J. Oliver, P. G. McMenamin, and P. G. Holt. 1991 Studies on the density, distribution, and surface phenotype of intraepithelial class II major histocompatibility complex (Ia)-bearing dendritic cells (DC) in the conducting airways. J. Exp. Med. 173:1345-1356.

23. Basset, F., P. Soler, and A. J. Hance. 1986. The Langerhans' cell in human pathology. Ann. NY Acad. Sci. 465:325-338.

24. Metcalf, D. 1986. The molecular biology and functions of the granulocytemacrophage colony-stimulating factors. Blood. 67:257-267.

25. Witmer-Pack, M. D., W. Olivier, J. Valinsky, G. Schuler, and R. M. Steinman. 1987. Granulocyte/macrophage colony-stimulating factor is essential for the viability and function of cultured murine epidermal Langerhans cells. $J$. Exp. Med. 166:1484-1498.

26. Heufler, C., F. Koch, and G. Schuler. 1988. Granulocyte/macrophage colony stimulating factor and interleukin 1 mediate the maturation of murine epidermal Langerhans cell into potent immunostimulatory dendritic cells. $J$. Exp. Med. 167:700-705.

27. Koch, F., C. Heufler, E. Kämpgen, D. Schneeweiss, G. Böck, and G. Schuler. 1990. Tumor necrosis factor $\alpha$ maintains the viability of murine epidermal Langerhans cells in culture but in contrast to granulocyte/macrophage colony-stimulating factor, without inducing their functional maturation. J. Exp. Med. 171:159-171.

28. Markowicz, S., and E. Engleman. 1990. Granulocyte-macrophage colony stimulating factor promotes differentiation and survival of human peripheral blood dendritic cells in vitro. J. Clin. Invest. 85:955-961.

29. Kupper, T. S., F. Lee, D. Coleman, J. Chodakewitz, P. Flood, and M. Horowitz. 1988. Keratinocyte derived T-cell growth factor (KTGF) is identical to granulocyte macrophage colony stimulating factor (GM-CSF). J. Invest. Dermatol. 91:185-188.

30. Watson, J. D., P. S. Crosier, C. J. March, P. J. Conlon, D. Y. Mochizuki, S. Gillis, and D. L. Urdal. 1986. Purification to homogeneity of a human hematopoietic growth factor that stimulates the growth of a murine interleukin 3-dependent cell line. J. Immunol. 137:854-857.

31. Tsuchiya, Y., M. Igarashi, R. Suzuki, and K. Kumagai. 1988. Production of colony-stimulating factors by tumor cells and the factor-mediated induction of suppressor cells. J. Immunol. 141:699-708.

32. Smith, S. M., D. K. P. Lee, J. Lacy, and D. L. Coleman. 1990. Rat tracheal 
epithelial cells produce granulocyte/macrophage colony stimulating factor. $\mathrm{Am}$ J. Respir. Cell. Mol. Biol. 2:59-68.

33. Amiot, M., A.' Bernard, B. Raynal, W. Knapp, C. Deschildre, and L. Boumsell. 1986. Heterogeneity of the first cluster of differentiation: characterization and epitopic mapping of three CD1 molecules on normal human thymus cells. J. Immunol. 136:1752-1758.

34. Stein, H., K. Gatter, H. Asbahr, and D. Y. Mason. 1985. Use of freezedried paraffin-embedded sections for immunohistologic staining with monoclonal antibodies. Lab. Invest. 52:676-683.

35. Burgess, A. W., C. G. Begley, G. R. Johnson, A. F. Lopez, D. J. Williamson, J. J. Mermod, R. J. Simpson, A. Schmitz, and J. F. Delamarter. 1987. Purification and properties of bacterially synthesized human granulocyte-macrophage colony stimulating factor. Blood. 69:43-51.

36. Bernaudin, J. F., K. Yamauchi, M. D. Wewers, M. J. Tocci, V. J. Ferrans, and R. G. Crystal. 1988. Demonstration by in situ hybridization of dissimila Il- $1 \beta$ gene expression in human alveolar macrophages and blood monocytes in response to lipopolysaccharide. J. Immunol. 140:3822-3829.

37. Broudy, V. C., K. Kaushansky, J. M. Harlan, and J. W. Adamson. 1987.
Interleukin 1 stimulates human endothelial cells to produce granulocyte-macrophage colony-stimulating factor and granulocyte colony-stimulating factor. $J$. Immunol. 139:464-468.

38. Sieff, C. A., S. Tsai, and D. V. Faller. 1987. Interleukin 1 induces cultured human endothelial cell production of granulocyte-macrophage colony stimulating factor. J. Clin. Invest. 79:48-51.

39. Murphy, G. F., B. R. Bronstein, R. W. Knowles, and A. K. Bahn. 1985. Ultrastructural documentation of M241 glycoprotein on dendritic and endothelial cells in normal human skin. Lab. Invest. 52:264-269.

40. Kaplan, G., G. Walsh, L. S. Guido, P. Meyn, R. A. Burkhardt, R. M. Abalos, J. Barker, P. A. Frindt, T. T. Fajardo, R. Celona, and Z. A. Cohn. 1992. Novel responses of human skin to intradermal recombinant granulocyte/macrophage-colony-stimulating factor: Langerhans cell recruitment, keratinocyte growth, and enhanced wound healing. J. Exp. Med. 175:1717-1728.

41. Gong J. L., K. M. McCarthy, J. Telford, T. Tamatani, M. Miyasaka, and E. E. Schneeberger. 1992. Intraepithelial airway dendritic cells: a distinct subset of pulmonary dendritic cells obtained by microdissection. J. Exp. Med. 175:797807. 